$\begin{array}{r}\text { Volume and Issues Obtainable at Center for Sustainability Research and Consultancy } \\ \text { Journal of Business and Social Review in Emerging Economies } \\ \text { ISSN: 2519-089X (E): 2519-0326 } \\ \text { Volume 6: No. 4, December 2020 } \\ \text { CSRC } \\ \text { Journal homepage: www.publishing.globalcsrc.org/jbsee } \\ \hline\end{array}$

\title{
The Assessment of Risk Management \& Engineering Management Practices at Project Planning Phase on Performance of Construction Projects
}

\author{
${ }^{1}$ Shahid Iqbal, ${ }^{2}$ M. Nabeel Ehtisham, ${ }^{3}$ Syed Farqaleet K. Bukhari, ${ }^{4}$ Shahid Mahmood \\ ${ }^{1}$ Assistant Professor, Management Studies Department, Bahria University, Islamabad Campus, Pakistan, \\ siqbal.buic@bahria.edu.pk \\ ${ }^{2}$ Managing Director, All Seasons Seed Corporation, Sahiwal, Pakistan, nabeelehtisham@gmail.com \\ ${ }^{3}$ MS (Project Management) student, Management Studies Department, Bahria University, Lahore \\ Campus, Pakistan, syedfarqaleet@ gmail.com \\ ${ }^{4}$ Lecturer, Institute of Aviation studies, University of Management and Technology, Lahore, Pakistan, \\ shahid-mahmood@umt.edu.pk
}

\begin{tabular}{l}
\hline ARTICLE DETAILS \\
\hline History \\
Revised format: November \\
2020 \\
Available Online: December \\
2020 \\
\hline Keywords \\
Project Risk $\quad$ Management; \\
Engineering $\quad$ Management, \\
Project $\quad$ Planning; \\
Construction Project Success \\
\hline
\end{tabular}

JEL Classification

M10, M11

\section{ABSTRACT}

Project Risk management is known as an important workout for the achievement of desired objectives for the construction projects. Success in construction project is quantified by attaining its enactment in terms of project quality, project cost, project time, project safety. Construction projects in Pakistan, typically in the whole world have a high risk of being pointedly late and over budget. However, a bit of schedule and cost related risks are unavoidable in any construction project around the world. It was found out that the engineers were generally nominated earlier the design phase of any project. Due to this reason maximum projects did not get the advantage from SMEs at the planning stage of the project. This study also supports that project managers who are engineers be involved in construction projects site selection, in preliminary budget and schedule development by using good Engineering Management Practices.

(C) 2020 Center for Sustainability Research and Consultancy Pakistan under a Creative Commons Attribution-NonCommercial-ShareAlike 4.0

Corresponding author's email address: nabeelehtisham@gmail.com

Recommended citation: Iqbal, S., Ehtisham, N., Bukhari, S. F. K. \& Mahmood, S. (2020). The Assessment of Risk Management \& Engineering Management Practices at Project Planning Phase on Performance of Construction Projects. Journal of Business and Social Review in Emerging Economies, 6(4), 1369-1378

\section{Introduction}

The motivation for this research is to have an in-depth analysis of a relationship between Risk management and project Performance. Focused area of research was risk management at planning phase and its overall effect on Construction Projects in Pakistan. A lot of work has already been done on the field of risk management related to performance of construction projects. Mostly the managing risks on construction projects is consider as part of project execution. But effect of Risk Management at planning stage is yet the area in Pakistani construction projects which need more intensive research in order to accomplish momentous performance. Due to the reason that the construction industry is one of the fastest growing industry of Pakistan with rate of $12.1 \%$ \& contributing $2.4 \%$ to the GDP of the 
country [State Bank of Pakistan (SBP) 2018], so the risk management at planning stage should be examined exploited to see the effect on project performance (Haider \& Kayani, 2020). Therefore, there is huge room of improvement and research gap is present to increase the performance of construction projects by analyzing the effect of risk management at planning phase of projects in Pakistan. Planning is actually vital part of a project concerning performance of project \& project success (Ahsan et al.,2020). It is a continuous and repeatable course throughout project life cycle. (Idoro, 2012). Previous research recommended that the companies must expand the performance by keeping this core phase of planning in mind (Lemma, 2014). Risk identification is an iterative process throughout the project lifecycle that includes the project team, project stakeholders and senior management affected by or who may affect the project outcome, and lastly external entities who can comment on the process of the risk identification on the basis of their past experience (Wysocki, 2004). Early identification of risks at planning phase or a tender of construction project and evaluating their comparative importance, the project management may be improved to decrease the risks and allot them to the groups who are best able to control them or engage them should they happen (Iqbal et al., 2020). Studies must be carried out at initial phases in the project life cycle, earlier choices are made to remain with the project (Thompson and Perry, 1992).

\section{Literature Review}

\subsection{Project Risk Identification}

Project Risk management is 01 of the 9th "knowledge areas" disseminated by the PMI - "Project Management Institute". PMBOK® Guide identifies the 09 "knowledge areas" distinctively for almost all projects. Risk Management is a difficult/crucial feature of the project management.

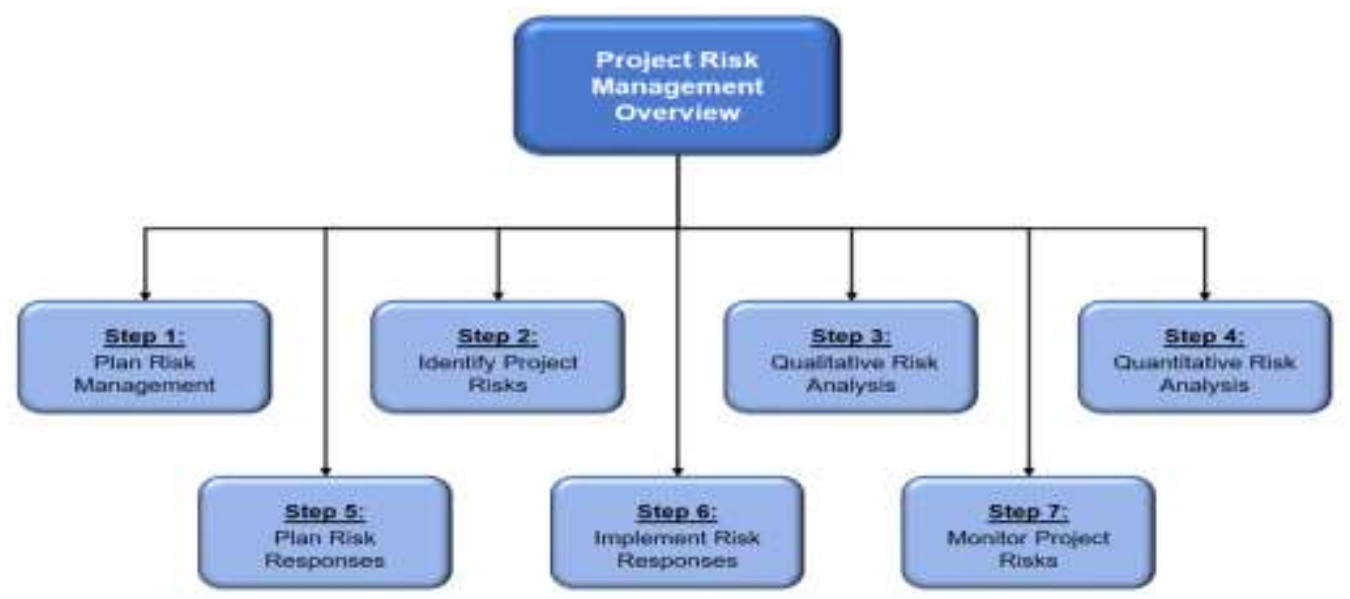

Fig 1: Project Risk Management overview

The Management of risk in the construction project setting is a complete \& systematic method for the categorizing, scrutinizing and retorting to risks to accomplish the project aims \& objectives (PMI, 2008; ICE, 2005). Main choices and influence on the high-quality of preparation and choice of construction should be complete at the initial phase of a project, Using the risk management and Engineering Management Practices at this initial phase of the project is very imperative (Eskesen, Tengborg, Kampmann, \& Veicherts, 2004).

The risk inspection \& Engineering Management methods have been defined by numerous authors (Cretu, 2011; Chapman C, 2003; Ahmed, 2007, Klemetti, 2006; Smith NJ, 2006). The identification of Risks contains the appreciation of likely risk event in the construction project \& clarification of the risk accountabilities (Wang, Dulaimi, \& Aguria, 2004). To identify \& restraint any project risks is so critical phase in controlling of the efficacious projects (Iqbal et al., 2020). According to "Practice Standard for Project Risk Management" (PMI,2009, p. 25) "risk cannot be succeeded except it is first renowned. So, afterward risk management process targets to classify all the intelligible risks to project objectives, 
though, it is very difficult to distinguish/find out all the risks at the start of a project"

\subsection{Engineering Management Practices}

The Engineering Management (EM) practices had been used all over the world from hundreds of years, Though, the academics and construction industry had used the practices Engineering Management (EM) for the last forty years. Engineering Management (EM) is usually linked with Industrial Engineering - as a common discipline. (Blanchard, B. S. 2004). The Strategies for Engineering Project Management is to systematized \& on time is critical for engineering project management. The greatest way for the ensuring that your project team might stay within the time limit i.e. schedule is by inferring ahead of time line how long each activity/milestone of project should execute. (Allen, et al.,2004). Engineer selection is ranked as $5^{\text {th }}$ major cause of construction projects failure out of 33 major causes identified (Dr.Manzoor.A.Khaldi, Causes of Construction Project Failures in Pakistan).Most of the time engineer is involved in design phase of the projects \& planning phase cannot get value input from expert engineer. Same observed in the case study of $1^{\text {st }}$ Panama Canal (H.Jng, J.C. Critn, \& M. Xu. M colocation (Meeting) on 16-12-2009).

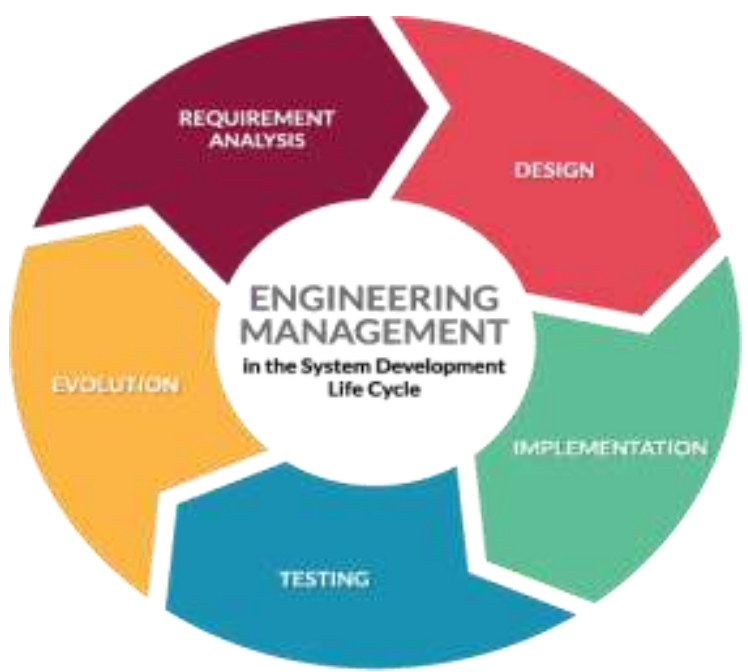

Fig 2: Engineering Management Practices in construction project management

\subsection{Project Site Selection}

In Pakistan site selection in many mega projects becomes difficult due to lack of early stakeholder engagement in projects like metro bus, orange line, \& past controversial projects like kala bagh dam.

Site selection is considered as one of the main factors which effects the project performance in all three aspects time, cost, scope. Site selection is ranked as $8^{\text {th }}$ major cause of construction projects failure out of 33 major causes identified (Dr. Manzoor.A.Khaldi, Causes of Construction Project Failures in Pakistan). The selection of site disturbs the organization, the visual qualities of a building; sustainability; massing; functionality; security; and lastly operation and economic efficiency (GSA, 2001, AlKahtani et al., 2020). The problem solving \& decision-making for site of venture is multifaceted (Ja, Bi, \& Adjuk, 2013).

\subsection{Projects Preliminary Budget \& Schedule}

For the development of an appropriate budget for the projects and its scheduling is a very important phase for the success of any construction project. Customers \& designers need to be come to an agreement on the expected price at early planning stage. It is so precarious phase as for as the cost management process is concerned. subsequently an erroneous budget can lead to meager project performance. 
It is a common mistake at the "planning stage" to use a schedule of housing with areas \& apply some past costs without making adjustments for the numerous "factors" which disturb the construction costs I,e, the size of project, its location, price of the project upsurges due to the reason that the date of the data was used and procurement method just like outsourcing ("WBDG, 2011").

\subsection{Project Time Performance}

The schedule of project can also have represented graphically by means of milestone charts, histograms, schedule network diagrams and bar charts of the project. The baseline of schedule is established from the network study of the schedule that was documented \& acknowledged by the project manager and its team as the baseline with start dates and end dates. The baseline is an important component in controlling and managing schedule.

The performance is assessed using techniques such as "SV - schedule variance", "SPI- schedule performance index" \& EVM - earned value management These methods support to weigh the degree of "SV - schedule variance". The "CCM critical chain method" associates the sum of buffer outstanding to the amount of buffer needed to protect the delivery date (PMI, 2008).

\subsection{Project Cost Performance}

"Cost is very significant factors of a project success throughout the life cycle of project management" (Azhar et al., 2008). Gido \& Clements (2003) stated cost as the most important parameter in project management and widely accepted in industry and literature. Earned Value Analysis (EVA) is used to analyze the cost performance of projects.

The task spending which originates from the arranging cycle must be practical, feasible, and developed on authoritatively arranged expenses and articulation of work. The financial backing ought to incorporate best gauges, chronicled expenses or modern designing measures as premise. The budget must recognize planned necessities of manpower, "MR - management reserve".

Execution results measures are quantitative dimensions \& include such things as, working cost, working amount, working nature and time-to-finish (Kerzner, 2009). It can be very easy or very complex when monitoring the project cost. In project management, one should also study the desires of all project stakeholders related to cost of project (Gido antd Clements, 2003).

Execution results measures are quantitative dimensions \& include such things as, working cost, working amount, working nature and time-to-finish (Kerzner, 2009).

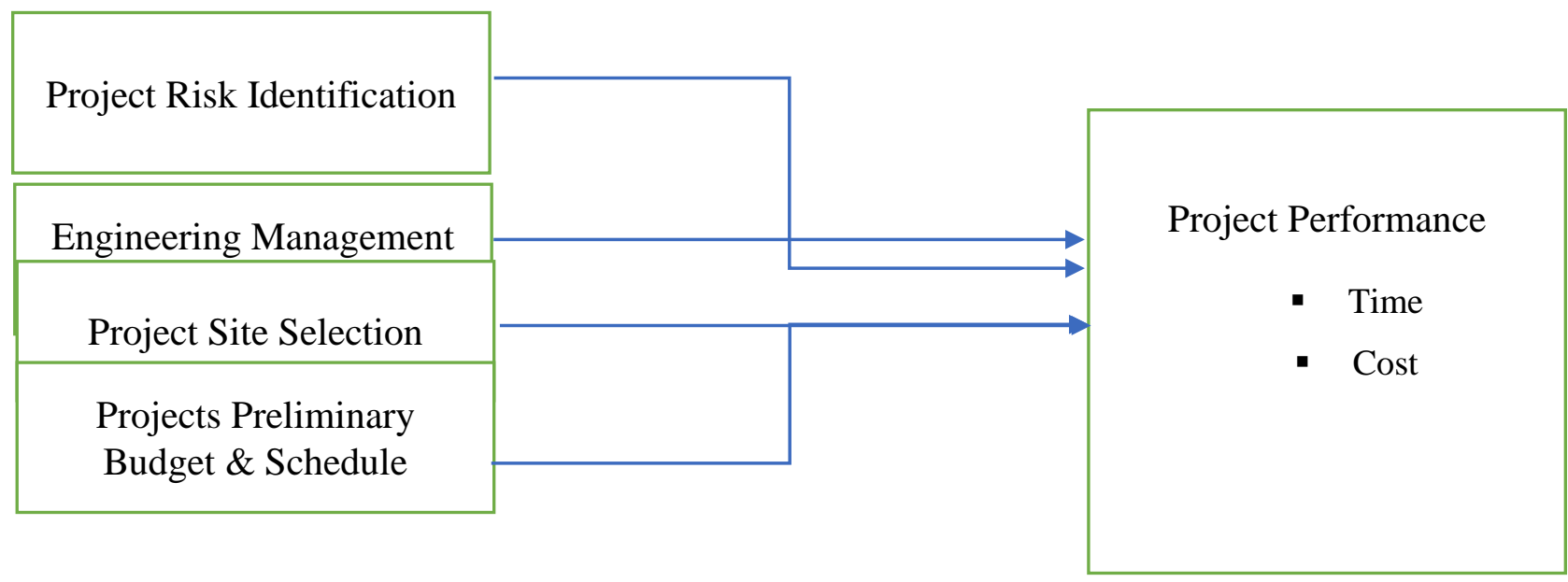

Figure 3: Research Model

H1: Project Risk identification at project planning phase is (+ive) positively related with 
Project success.

H2: Engineer Management Practices are (+ive) positivity associated with Project Success.

H3: Project Site Selection is (+ive) positivity associated with Project success.

H4: Project Preliminary Budget and Schedule is (+ive) positivity associated with Project success.

\section{Research Methodology}

The proposed study is design to get opinions from project managers, consulting engineers, architects, quantity surveyors \& contractors with respect to project risk management and schedule and cost performance in project planning phase. In order to collect primary data questionnaire was adapted. Online survey was used out of various available approaches to collect data for the research study. Online questionnaire was distributed to the respondents through Email and WhatsApp. A survey method has been used extensively prior as well, so the respondents are comfortable in answering survey questions. All responses are collected through online questionnaire as respondents were uneasy to fill the hardcopy of the questionnaire.

\subsection{Population}

The population of the research study consist of registered engineers, project managers and professionals related to construction industry in Pakistan. The key clients in construction industry are Water and Power Development Authority of Pakistan (WAPDA), Planning and Development (P\&D) Punjab, Sindh, KPK, Baluchistan, Azad Jammu Kashmir \& Gilgit Baltistan (AJ\&K, GB) and Irrigation Department of Pakistan. The main contractors working in construction industry of Pakistan are Descon Engineering ltd, Banu Mukhtar Contracting ltd, Frontier Works Organization and many more. The main consultants in construction industry of Pakistan are Descon Engineering ltd, SMEC Pakistan, Pakistan Engineering Services (PES), Mott MacDonald Pakistan (MMP). The regularity authorities are Public Procurement Regulatory Authority PPRA, Provisional Government Regulatory Authorities.

The sampling frame consist of engineers/ architects, project managers, and senior managers working at mega construction projects. The targeted population for sampling of data involves client, contractor and consultant of the following Projects Gulpur Hydro Power Project (AJ\&K), Kurram Tangi Multi-Purpose Dam (KPK), Guddu Barrage (Punjab). Karot Dam Project (AJ\&K), Wind Farm (Sindh) Six to Twelve Mega Projects of Pakistan's Construction Industry.

\subsection{Place of Study}

The research study was conducted on five to ten mega construction projects of Pakistan. Almost one mega project from each region of the country.

\subsection{Sample Size}

Hair et. al. (2006)" the choice of sample size is representing of your target respondents effectively as it is difficult for the researcher to get the sample from whole population". Some researchers think that sample size should not be very small or very large and should be within suitable range of 100 to 200 samples for proper data analysis. Green (1991)" sample size may be identified from the number of independent variables used in the research study". Cohen (1968) says that "larger is better". "Some of the researchers have developed the rule of thumb for selecting 10-15 samples collection for each independent variable" (Field 2012). So therefore, a sample size of 5 to 10 mega construction projects with overall 200 samples was proposed for the research study. A total of 215 responses were received with $100 \%$ background from construction industry.

\subsection{Data Collection Tool}

Survey technique was adopted for the collection of data. Questionnaire was made accessible in hard printed formatted as well as electronically for respondent convenience. Instruction regarding the 
questionnaire were mentioned on it to remove any ambiguity. The questionnaire did not contain identity, personal contact information, information related to company confidentiality so that the research respondents do not feel hesitation to fill the online questionnaire.

\subsection{Data Processing and Analysis}

Analysis is a collaborative process by which answers are studied to see whether the results are related to each research question (Backstrom \& Hursh-Cesar, 1981). Data Analysis is a technique of gathering, converting, validating, and modeling the data with purpose of determining the required information. The results so acquired are communicated, proposing conclusions, and supporting decision-making. Quantitative analysis of data contains the calculation of frequencies of variables and variances between variables. A quantitative approach is usually related with discovering evidence to either accept or reject the hypotheses we have framed at the former phase of our research process. Statistical Package for Social Sciences (SPSS) was used to perform quantitative statistical analysis for questionnaire. Regression and correlation tests were performed to examine the connection between the independent and dependent variables involved in the research study.

A Sample size of 6 to 12 mega construction projects with overall 250 samples was proposed for the research study. A total of 215 valid responses were received with $100 \%$ background from construction industry as shown in the table below:

Response Table (a) Stats

\begin{tabular}{|ll|r|}
\hline N & Valid & 215 \\
& Missing & 0 \\
\hline
\end{tabular}

\subsection{Data Analysis Technique}

The method of data analysis includes gathering of the data, its arrangement, descriptive statistics, frequency statistics and analysis of respondent's demographics, calculating reliability measures, and performing the correlation. SPSS was used for the analysis. Hypotheses were verified and tested by applying regression and correlation analysis.

\subsection{Project Risk Identification and Project Performance}

The below given data indicates that "Project Risk Identification: was a good independent variable for Project Performance. In this analysis where variable "Project Risk Identification" is independent variable and dependent variable is "Project Performance", the value of adjusted R square is (.174) which shows the fitness of this model. $\beta$ value is (.425) which implies that $49.4 \%$ of variations occur in the dependent variable due to $1 \%$ change in the independent variable. The "F" Value (30.606) shows that the hypothesis is acceptable because the value of " $T$ " is greater than " 2 " which is 4. 528. Model is fit because significance value is 0.00 which shows the significant relationship of both variable i.e. Independent variable and dependent variable. $\beta$ value is also in permissible range. So, the model is an excellent depiction of result. Hence, therefore hypothesis $\mathbf{H 1}$ is accepted.

$\operatorname{Mod} \operatorname{Summary}(\mathbf{R I})$

\begin{tabular}{|c|c|c|c|c|}
\hline Mod & $(\mathrm{R})$ & (R) Squr. & Adjusted R Squr. & $\begin{array}{l}\text { Std. Error of the } \\
\text { Estim. }\end{array}$ \\
\hline 1 & $.425^{\mathrm{a}}$ & .178 & .167 & 2.95322 \\
\hline
\end{tabular}


a. Predic: (Const), RI

\begin{tabular}{|ll|r|r|r|r|r|}
\hline \multicolumn{1}{|l|}{} & Sum of Squr. & df & Mean Squr. & F & \multicolumn{1}{c|}{ Sig. } \\
\hline 1 & Reg & 176.730 & 1 & 177.730 & 20.505 & $.000^{\mathrm{b}}$ \\
& Resi & 868.108 & 249 & 8.668 & & \\
& Total & 1055.691 & 250 & & & \\
\hline
\end{tabular}

a. Depend Vari: PRJPER

b. Predic: (Const), RI

\subsection{Engineering Management Practices}

shows the results of reliability test, which shows the value of Cronbach's $(\alpha) .763$ for the no of items 13 used, which is in threshold limit and validates that the data is reliable. Table highlights the descriptive Statistics of engineer/architect selection (EAS), as shown in the table engineer/architect selection achieved mathematical mean of 3.9013 and standard deviation of .49765 . Skewness and kurtosis are also in permissible range.

Table (a) Reliability Stats(EAS)

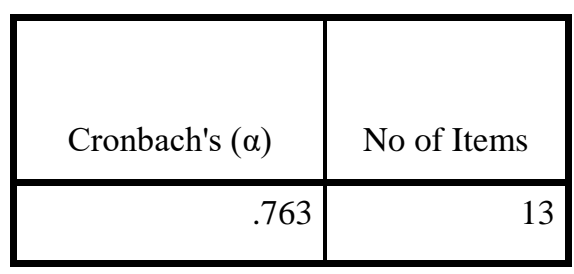

Table (b) Descr. Stats (EAS)

\begin{tabular}{|l|c|c|c|c|c|c|c|c|r|}
\hline & $\mathrm{N}$ & Min & Max & Mean & Std. Devi & \multicolumn{2}{|c|}{ Skewness } & \multicolumn{2}{|c|}{ Kurtosis } \\
\cline { 2 - 10 } & Stats & Stats & Stats & Stats & Stats & Stats & Std. Error & Stats & Std. Error \\
\hline Engineer Architect Selection & 215 & 1.93 & 5.10 & 3.9013 & .49765 & -.173 & .249 & 2.265 & .474 \\
No & 215 & & & & & & & & \\
\hline
\end{tabular}

\subsection{Correlation}

The correlation analysis indicated a strong correlation between the Engineering Management Practices and project performance. It is identified that the relationship is significant at $99 \%$ level of confidence, which shows that variables are strongly connected with one and other. Variables functionality, time, cost and communication are positively related with method and time of Engineering Management Practices with strong relation at significance level 0.01, which is also depicted in the table below. All the variables are positively related with each other. All results depict the variables are related with each other and with project performance parameters. The Engineering Management Practices is positively related to project success is in line with the previous literature and research.

\subsection{Project Site selection}

Table shows the results of reliability test for site selection variable data, which shows the value of Cronbach's $(\alpha) .798$ for the no of items 8 used, which is in threshold limit and validates that the data is 
reliable.

Table Reliability Stats

\begin{tabular}{|r|r|}
\hline Cronbach's $(\alpha)$ & No of Items \\
\hline .758 & 11 \\
\hline
\end{tabular}

Table Case Summary

\begin{tabular}{|c|r|r|}
\hline & No & \multicolumn{2}{|c|}{ Per\% } \\
\hline Valid & 211 & 97.1 \\
Exclua $^{a}$ & 4 & 2.9 \\
Total & 215 & 100.0 \\
\hline
\end{tabular}

Table highlights the descriptive Statistics of engineer/architect selection (EAS), as shown in the table engineer/architect selection achieved mathematical mean of 3.4938and standard deviation of .63624. Skewness .040 and kurtosis .484 are also in permissible range.

Table Descr. Stats (SS)

\begin{tabular}{|l|r|r|r|c|c|c|c|c|c|}
\hline & N & Min & Max & Mean & Std. Devi & \multicolumn{2}{|c|}{ Skewness } & \multicolumn{2}{|c|}{ Kurtosis } \\
\cline { 2 - 10 } & Stats & Stats & Stats & Stats & Stats & Stats & Std. Error & Stats & Std. Error \\
\hline SS & 215 & 1.76 & 5.03 & 3.5641 & .64021 & .041 & .242 & .479 & .480 \\
valid No & 215 & & & & & & & & \\
\hline
\end{tabular}

\subsection{Project Preliminary Budget and Schedule}

The below given data indicates that "Preliminary Budget and schedule development" was weak independent variable for Project Performance. In this analysis where variable "Preliminary Budget and schedule development" is independent variable and dependent variable is "Project Performance", the value of adjusted $\mathrm{R}$ square is (.131) which shows the fitness of this model. $\beta$ value (.390) which implies that $37 \%$ of variation will be observed in the dependent variable because of $1 \%$ change in the independent variable. The "F" Value (15.046) Shows that the hypothesis are acceptable because the value of "T" is greater than " 2 " which is 3. 879. Model is fit because significance value is 0.00 which shows the significant relationship of both variable i.e. Independent variable and dependent variable. $\beta$ value is also in permissible range. So, the model is an excellent depiction of result. Hence, therefore hypothesis $\mathrm{H} 4$ is accepted.

Table Mod Summary (BSD)

\begin{tabular}{|l|r|r|r|r|}
\hline Mod & $\mathrm{R}$ & \multicolumn{1}{|c|}{ R Squr. } & \multicolumn{1}{c|}{ Adjusted R Squr. } & \multicolumn{1}{c|}{$\begin{array}{c}\text { Std. Error of the } \\
\text { Estimate }\end{array}$} \\
\hline 1 & $.390^{\mathrm{a}}$ & .137 & .131 & 3.06071 \\
\hline
\end{tabular}

a. Predic: (Const), BSD 
Table F ${ }^{\mathrm{a}}$ (BSD)

\begin{tabular}{|ll|r|r|r|r|r|}
\hline Mod & & Sum of Squr. & df & Mean Squr & F & \multicolumn{1}{c|}{ Sig. } \\
\hline 1 & Reg & 140.950 & 1 & 140.950 & 15.046 & $.000^{\mathrm{b}}$ \\
& Resi & 889.957 & 95 & 9.368 & & \\
& Total & 1030.907 & 96 & & & \\
& & & & & \\
\hline
\end{tabular}

a. Depend Vari: PRJPER

b. Predic: (Const), BSD

\section{Conclusion and Recommendations}

The research study showed that Project Risk Management Practices \& Engineering Management Practices at the stage of the "planning phase" had an influence on project performance. This study also demonstrates that the construction projects in Pakistan had some input from a skilled architect and engineer. Though, most of the participants had not studied the subject of risk management. Pakistan's construction industry is the major industry of the country contributing significantly to the social and economic development growth of Pakistan. The expenses on development schemes in Pakistan for year 2018-2019 is projected at Rs 1,152.1 billion Pakistani Rupees, which is equivalent to $19.4 \%$ of total budget. Extensive research is required in the field of risk management with respect to construction industry to better optimize the allocated budget. Very little research evidence is available in context to Pakistan's construction industry. The researcher recommends the similar study including more projects with increase sample size. It is also recommended to conduct longitudinal study instead of crosssectional to increase the accuracy and updating of data collection.

\section{References}

Ahmed, A., Kayis, B., \& Amornsawadwatana, S. (2007). A review of techniques for risk management in projects. Benchmark International Journal, 14(1), 22-36

Ahsan, Z., Haider, S. A., Kayani, U. N., \& Nawaz, S (2020). Impact of Ambidextrous Leadership on Project Success with the Mediating Role of Innovation and Moderating Role of Self-Efficacy. Abasyn Journal of Social Sciences. 13(1).

AlKahtani, N., Iqbal, S., Sohail, M., Sheraz, F., Jahan, S., Anwar, B., \& Haider, S. (2020). Impact of employee empowerment on organizational commitment through job satisfaction in four and five stars hotel industry. Management Science Letters, 11(3),

Allen, T. J., \& Sosa, M. L. (2004). 50 years of engineering management through the lens of the IEEE transactions. Transactions on Engineering Management, 51(4), 391395.

Assaf, S., \& Al-Hejji, S. (2006). Causes of delay in large construction projects. International Journal of Project Management, 24(4), 349-357. Retrieved from Central Development Working Party (CDWP,2018)

Blanchard, B. S. (2004). System Engineering Management. John Wiley \& Sons

Choge, K. J., \& Muturi, W. M. (2014). Factors affecting adherence to cost estimates: A survey of construction projects of Kenya National Highways Authority. International Journal of Social Sciences and Entrepreneurship, 1, 689-705.

Dvir, D., Raz, T., \& Shenhar, A. J. (2003). An empirical analysis of the relationship between project planning and project success. International journal of project management, 21(2), 89-95.

Eskesen, S. D., Tengborg, P., Kampmann, J., \& Veicherts, T. H. (2004). Guidelines for tunnelling risk management, International Tunnelling Association (19(3)).

Fageha, M. K., \& Aibinu, A. A. (2014). A Procedure for Involving Stakeholders when Measuring ProjectScope Definition Completeness at Pre-project Planning Stage. AIPM NATIONAL 2014 
CONFERENCE PROCEEDINGS, 1-8. Retrieved from

Flanagan, R., Norman, G., \& Chapman, R. (2006). Risk management and construction (2 ${ }^{\text {nd }}$ ed.). Oxford: Blackwell Publisher

Gitau 1m, 2015.the effects of risk management at project planning phase on performance of construction projects in rawanda. A dissertation of MS thesis.

GSA (2001). The Site Selection Guide (1st ed.). Washington DC: AIA.

Haider, S. A., \& Kayani, U. N. (2020). The impact of customer knowledge management capability on project performance-mediating role of strategic agility. Journal of Knowledge Management. https://doi.org/10.1108/JKM-01-2020-0026

Hyunju Jeong, John C. Crittenden, and Ming Xu Messner Meeting on Dec 16, 2009. Panama Canal case study.

ICE (2005). RAMP - Risk Analysis and Management for Projects: A Strategic Framework for Managing Project Risk and its Financial Implications (2nd ed.). London: Thomas Telford Publishing

Idoro, G. (2012). Evaluating levels of project planning and their effects on performance in the Nigerian construction industry. Construction Economics and Building, 9(2), 39-50

Iqbal, S., Bukhari, S. F. K., Riaz, A. R., \& Haider, S. A. (2020). Assessment of Sustainable Competitive Advantages and Influences through Project Management Practices of Construction Industry of Pakistan. Journal of Business and Social Review in Emerging Economies, 6(3), 1199-1209.

Iqbal, S., Rehman, K., Asghar, W., \& Haider, S. A. (2020). Comparative Analysis of Effective Project Governance Practices and Benefit Realization Management for the Successful Execution of Projects in NGO Industry. Journal of Accounting and Finance in Emerging Economies, 6(4).

Kaplan, S. (1997). The words of risk analysis. Risk Analysis (17), pp. 407-417.

Kerzner, H. (2009). Project Management: A systems approach to planning, scheduling, and controlling (10th ed.). New Jersy: John Wiley and Sons.

Lemma, T. (2014). The role of project planning on project performance in Ethiopia. A Dissertation of MA Thesis.

Morris, P., \& Hough, G. H. (1988).The Anatomy of Major Projects: A Study of the Reality of Project Management (1st ed.). New York: Wiley

Murphy, D. C., Baker, B. N., \& Fisher, D. (1974). Determinants of project success, Grant No. NGR 22003-028 for National Aeronautics and Space Administration, Management Institute, School of Management, Boston College, Boston, MA

Olwale, Y. A., \& Sung, M. (2010). Inhibiting factors and mitigating measures in practice.Construction Management and Economics,28, 509-526.

Parker, D., \& Mobey, A. (2004). Action research to explore perceptions of risk in project management. International Journal of Productivity and Performance Management, 53(1), 18-32.

PMI (2018). Project Management Body of Knowledge (PMBOK Guide) (6th ed.) Pennsylvania, USA: Project Management Institute In

Raz, T., \& Michael, E. (2001). Use and benefits of tools for project risk management. International journal of project management, 19(1), 9-17.

Regulation, 2010 for Procurement of Consultancy Services. State Bank of Pakistan (SBP) 2018, third quarterly report.

Wallace, P., \& Blumkin, M. (2007). Major Construction Projects: Improving Governance and Managing Risks. Retrieved from www.deloitte.com

Wang, S. Q., Dulaimi, M. F., \& Aguria, M. Y. (2004). Risk Management Framework for Construction Projects in Developing Countries. Construction Management Economi cs, 22(3), 237-252.

WAPDA Progress report, 2018 http://www.wapda.gov.pk/index.php/projects/hydro-power/underconstruction/kurram-tangi-dam

Zhang, H. (2007). A redefinition of the project risk process: Using vulnerability to open up the eventconsequence link. International journal of project management, 25(7), 694- 701.

Zhou, P. X., Zhang, G. M., \& Wang, J. (2007). Understanding the Key Risks in Construction Projects in China. International Journal of Project Management, 25, 601-614. 